\title{
4-H ENERGY ENCOUNTERS
}

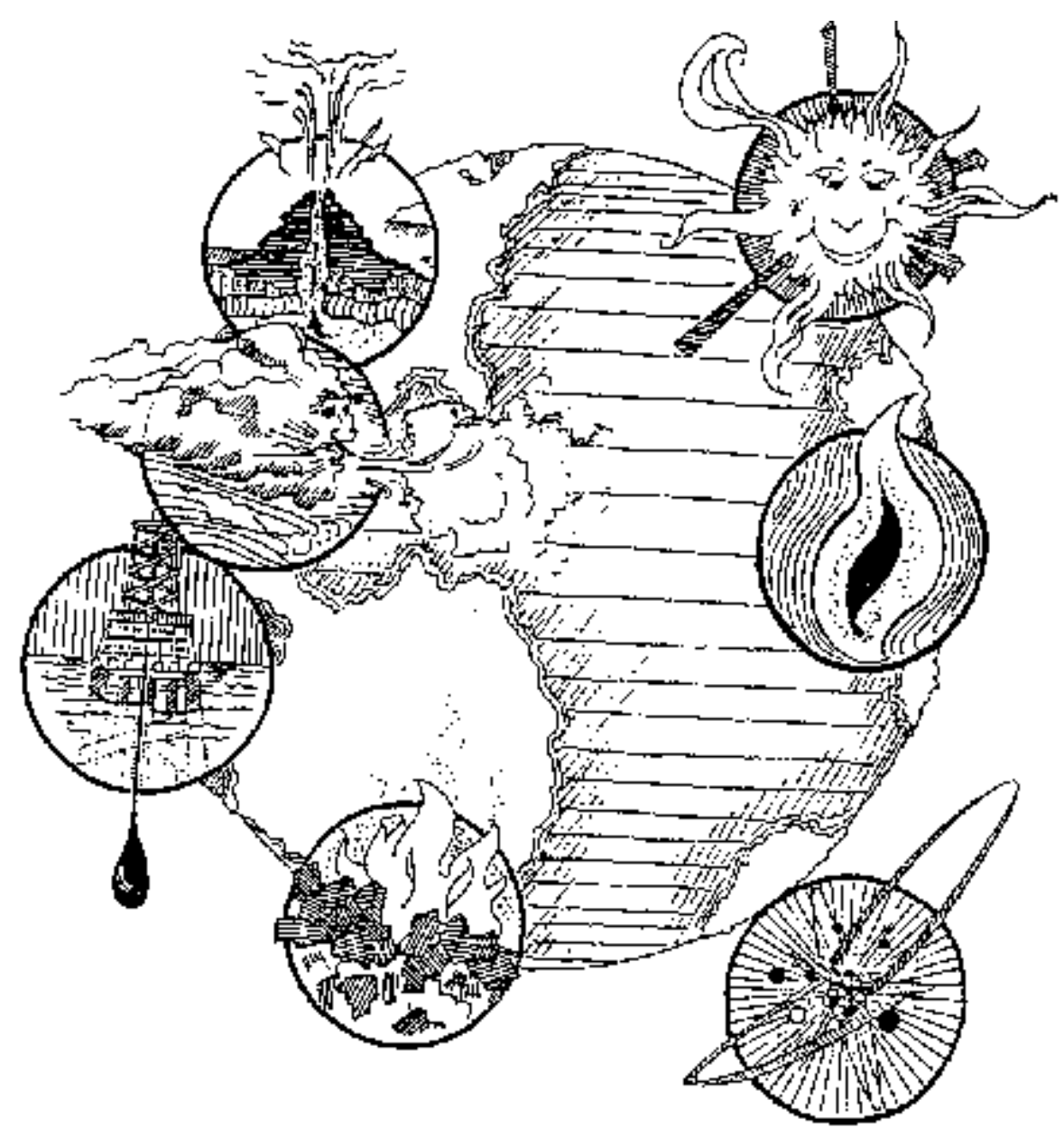

UNIVERSITY OF FLORIDA

IFAS EXTENSION

The Department of 4-H and Other Youth Programs, University of Florida Cooperative Extension, Institute of Food and Agricultural Sciences, April, 1993, May, 1996; reviewed, 2002.

COOPERATIVE EXTENSION SERVICE, UNIVERSITY OF FLORIDA, INSTITUTE OF FOOD AND AGRICULTURAL SCIENCES, Christine T. Stephens, director, in cooperation with the United States Department of Agriculture, publishes this information to further the purpose of the May 8 and June 30, 1914 Acts of Congress; and is authorized to provide research, educational information and other services only to individuals and institutions that function without regard to race, color, sex, handicap or national origin. Single copies of extension publications (excluding 4-H and youth publications) are available free to Florida residents from county extension offices. Information on bulk rates or copies for out-of-state purchasers is available from C.M. Hinton, Publications Distribution Center, IFAS Building 664, University of Florida, Gainesville, Florida 32611. Before publicizing this publication, editors should contact this address to determine availability. Printed 4/93, 5/96. 


\title{
CREDITS AND ACKNOWLEDGEMENTS
}

4-H ENERGY ENCOUNTERS was developed through a team effort of the Department of 4-H and Other Youth Programs, Institute of Food and Agricultural Sciences, University of Florida.

This curriculum package was created by Linda Barber, 4-H Agent-Santa Rosa County, Marilyn Simmons, 4-H/Home Economics Agent-Levy County, Craig R. Miller, Educational Materials Coordinator, Department of 4-H and Other Youth Programs, University of Florida Institute of Food and Agricultural Sciences.

Technical review and assistance was provided by the following members of the Cooperative Extension Service Environmental Education - Energy Design Team (FL610): Nancy P. Arny, Associate Professor and Extension Specialist, Department of Forestry, University of Florida, Institute of Food and Agricultural Sciences, Tammy Calder, Project Assistant, M. Joy Cantrell, Associate Professor and 4-H Youth Development Curriculum Specialist, Department of 4-H and Other Youth Programs, University of Florida Institute of Food and Agricultural Sciences, Paula Donaldson, Florida Energy Office, Vicki Mullins, Teacher-Santa Rosa County, Sylvia Scheck, Project Assistant-Levy County, Helen Whiffen, Energy Extension Specialist-University of Florida, Institute of Food and Agricultural Sciences, and Deborah J. Glauer, Educational Resource Coordinator, Department of 4-H and Other Youth Programs, University of Florida.

Artist: Special thanks to Bennie Brasington for the cover design of 4-H Energy Encounters Leader's Guide and 4-H Energy Encounters Workbook.

Special acknowledgement of contributions and thanks are also extended to Jeneen Drake, Connette Williams, Nancy Stuart, Angela Frampton, Trey Killingsworth, Department of 4-H and Other Youth Programs, for the word processing and computer graphics.

\section{ACKNOWLEDGEMENTS...}

The following program was pilot-tested in Levy and Santa Rosa Counties.

\section{RESOURCES..}

Energy Encounters includes materials adapted from:

\author{
E Cubes, University of Florida, IFAS \\ Energy Bridges, Florida Middle School Energy Project \\ Energy Safari, Hillsborough County Extension \\ Harness Atom, U.S. Department of Energy \\ That Mysterious Source..The Sun, Palm Beach County Extension \\ Watt Watchers 4-H Energy Series, University of Florida, IFAS
}

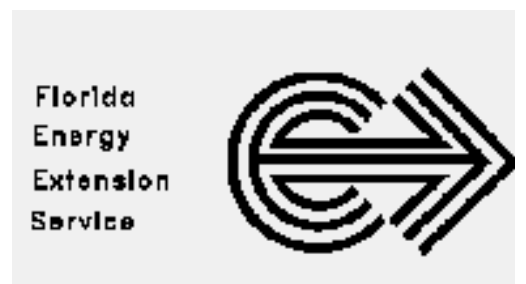

ENERGY ENCOUNTERS has been prepared using funds from the Florida Energy Extension Service and is the sole property of the State of Florida. Information concerning the use, display or reproduction of this material may be obtained by contacting the Florida Cooperative Extension Service.

The Florida Energy Extension Service receives funding from the Florida Energy Office, Department of Community Affairs and is operated by the University of Florida's Institute of Food and Agricultural Sciences through the Cooperative Extension Service. The information contained herein is the product of the Florida Energy Extension Service and does not necessarily reflect the views of the Florida Energy Office. 


\section{PREFACE}

\section{4-H ENERGY ENCOUNTERS}

The new Florida 4-H Environmental Education curriculum, OUR NATURAL WORLD, includes a basic premise, i.e., our environment is a web of cooperation and interdependence. One of the five key components of the curriculum is Energy Education.

4-H Energy Encounters of OUR NATURAL WORLD, is designed to help 9-11 year old youths to understand the environmental and economic issues associated with ENERGY. Additional curriculum packages will be designed for youth in other age ranges and for sequential advancement in energy education.

To the informed Florida citizen, it is not surprising that energy commands a priority within the total 4-H Environmental Education curriculum. An investment in young people's knowledge, understanding and attitudes about energy origins, uses, and conservation issues and their affect on the natural environment can not be ignored now or in the future.

In 4-H ENERGY ENCOUNTERS, we are particularly interested in helping young people develop a personal environmental ethic and to understand each person's individual impact on energy's consumption and availability.

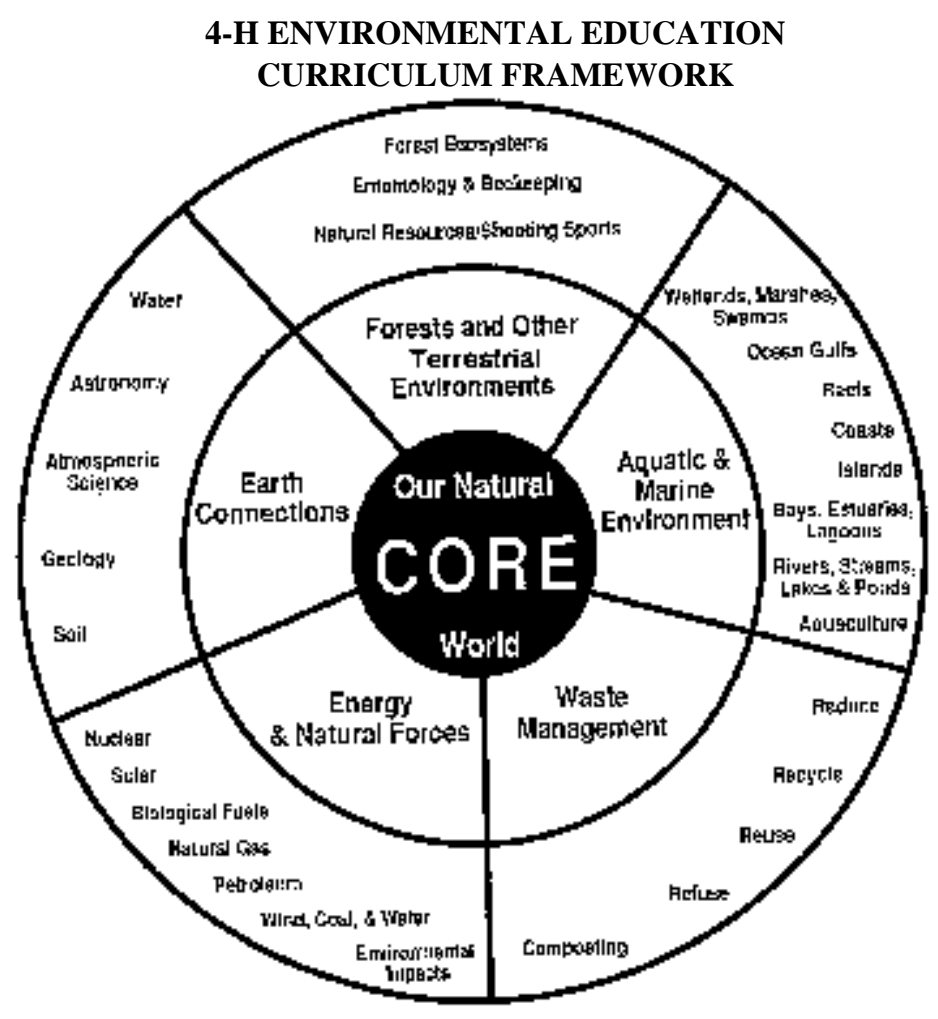

DEPARTMENT OF 4-H \& OTHER YOUTH PROGRAMS INSTITUTE OF FOOD AND AGRICULTURAL SCIENCES UNIVERSITY OF FLORIDA 


\section{TABLE OF CONTENTS}

\section{INTRODUCTION}

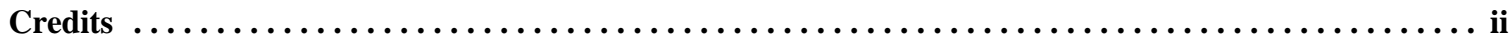

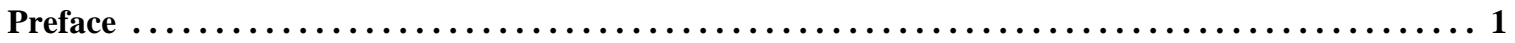

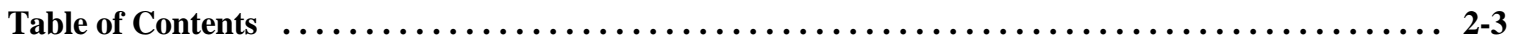



About Experiential Education $\ldots \ldots \ldots \ldots \ldots \ldots \ldots \ldots \ldots \ldots \ldots \ldots \ldots \ldots \ldots \ldots \ldots \ldots \ldots \ldots \ldots \ldots, 6,8$

II. ENERGY ENCOUNTERS

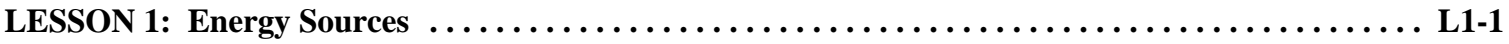

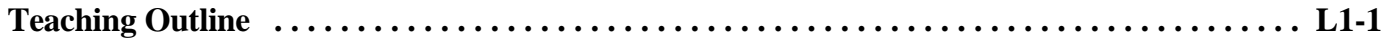

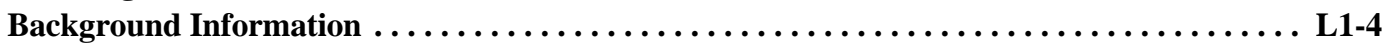

Activities

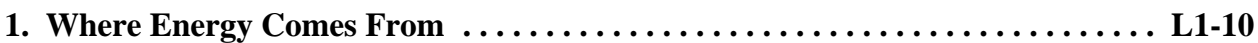

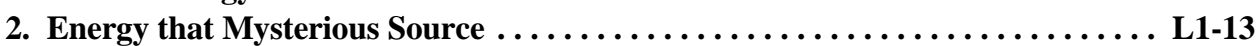

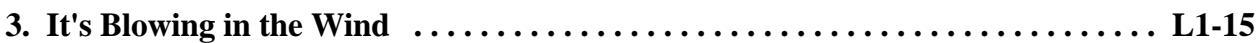

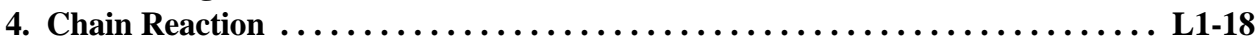

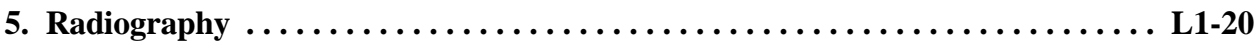

6. Energy Mobiles $\ldots \ldots \ldots \ldots \ldots \ldots \ldots \ldots \ldots \ldots \ldots \ldots \ldots \ldots \ldots \ldots \ldots \ldots \ldots \ldots \ldots \ldots \ldots \ldots, 22$

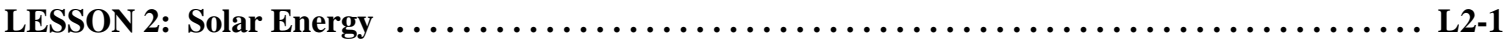

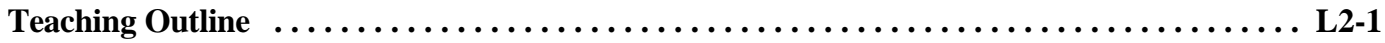

Background Information $\ldots \ldots \ldots \ldots \ldots \ldots \ldots \ldots \ldots \ldots \ldots \ldots \ldots \ldots \ldots \ldots \ldots \ldots \ldots \ldots \ldots, \mathbf{L} 2-3$

Activities

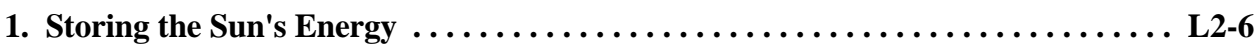

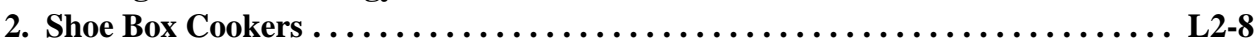

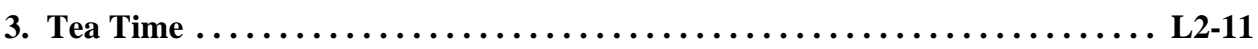

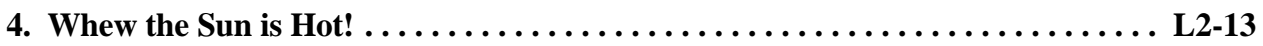

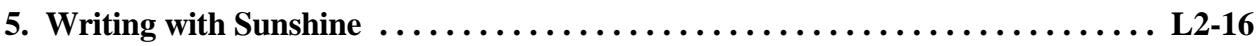



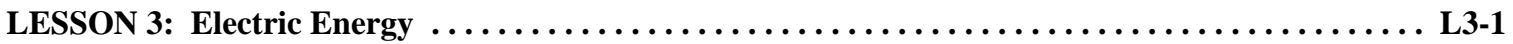

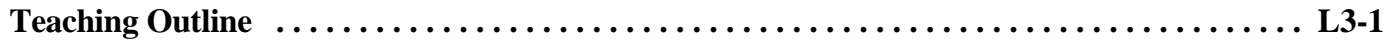

Background Information $\ldots \ldots \ldots \ldots \ldots \ldots \ldots \ldots \ldots \ldots \ldots \ldots \ldots \ldots \ldots \ldots \ldots \ldots \ldots \ldots$, L3-3

Activities

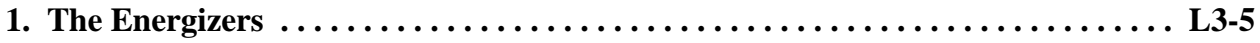

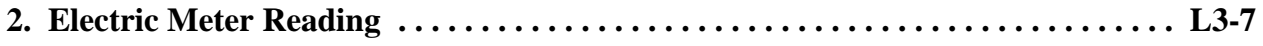

3. Electricity and How it Influences Your Life $\ldots \ldots \ldots \ldots \ldots \ldots \ldots \ldots \ldots$ L3-10

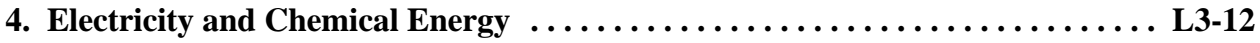



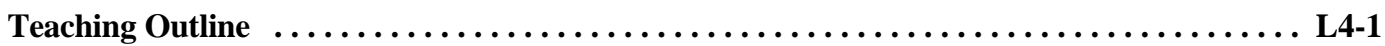

Background Information $\ldots \ldots \ldots \ldots \ldots \ldots \ldots \ldots \ldots \ldots \ldots \ldots \ldots \ldots \ldots \ldots \ldots \ldots$, L4-3

Activities

1. What's in Here? .........................................44-6



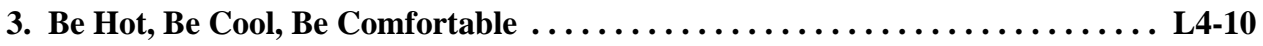






\section{TABLE OF CONTENTS (continued)}

II.

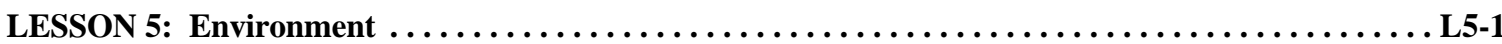

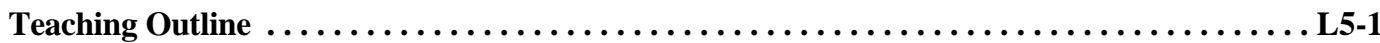

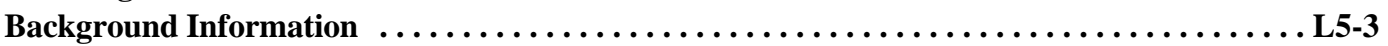

Activities

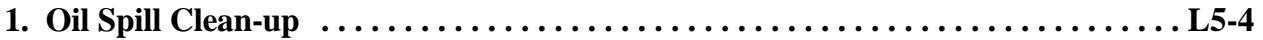

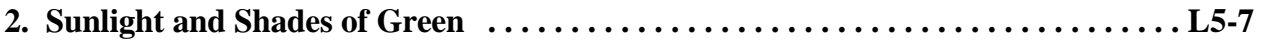



4. Make it! ...............................................

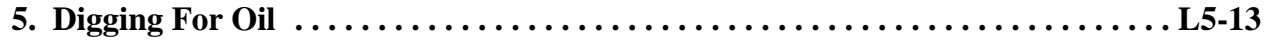

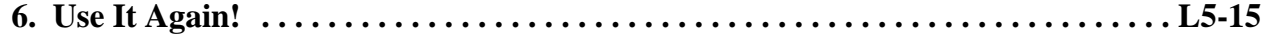

III. TAKE HOME ACTIVITIES

IV. EVALUATION AND RECOGNITION MATERIALS

V. SUPPLEMENTAL ACTIVITIES 


\section{About Energy Encounters}

The development of this 4-H Environmental Education Project Kit was driven by two basic principles:

1. Learning about energy can be fun! The kit provides simple and inexpensive, yet fun activities that teach youth about major energy concepts, including the energy sources, energy uses, and energy conservation.

2. 4-H volunteer teaching activities must be ready-to-use. This project includes materials needed to conduct energy education activities into an easy-to-use format. It was designed to be teacher friendly and takes much of the guesswork out of teaching this subject.

\section{AGE OR GRADE LEVELS}

This project was developed for youth ages 9-11. Both group and individual activities encourage participation and action in all aspects of energy education. Teachers and volunteers are encouraged to select learning activities that are most suitable to their youth. The overall intent is to facilitate learning and to spark creativity in both teachers and youth.

\section{CONTENTS}

The following resources are components of the 4-H Energy Program:

! LEADER'S GUIDE - This three-ring notebook contains a complete, easy-to-read outline for lessons. Each lesson provides a variety of activities that can be conducted depending upon the time frame devoted to this project. The following activities are a mix of games, experiments, role plays or demonstrations that help to teach the basic principles and concepts in each lesson. The lesson concludes with a review using activity sheets in the youth's Workbook and discussion questions for youth to REFLECT and APPLY.

! ENERGY ENCOUNTERS WORKBOOK - contains activity sheets for youth that correspond to each lesson. A variety of activities including puzzles, word searches, connect-the-dots, and other instructional activities make up this fun booklet.

! TEACHING KITS - containing materials needed for many of the activities. Solar Ovens are also available to enhance teaching (contact your County Extension Service for more information). 


\section{LESSON PROFILES}

A brief description of the five Energy Encounters Lessons:

\section{! LESSON 1 - ENERGY SOURCES}

Energy is everywhere. The sources of energy are essential in understanding the importance of energy and the environment. Youth discover energy sources and energy use, discovering how energy changes forms. Lesson 1 explores energy sources, renewable and non-renewable forms.

\section{! LESSON 2 - SOLAR ENERGY}

The sun provides an excellent "hands-on" learning opportunity for exploring just how the sun provides energy to plants and animals. Several activities explore solar power. Youth make their own solar cookers and discover how the sun can be used to do a variety of work.

\section{! LESSON 3 - ELECTRIC ENERGY}

The influence that electric power has had on humans is explored. Youth learn how to read an electric meter and discover what a kilowatt-hour can provide. Learning how electricity is produced helps youth understand the uses of natural resources in providing electricity.

\section{! LESSON 4 - ENERGY CONSERVATION}

The need for conserving natural resources is an important concept in energy education. Lesson 4 helps youngsters explore ways that they can conserve energy and natural resources. Math skills are used by youth to calculate cost associated with operating electric appliances (AC/Heat) to determine the efficiency of operating.

\section{! LESSON 5 - ENVIRONMENT}

After learning about energy sources, how we use energy, and conservation practices, Lesson 5 introduces the concerns of the environment. The importance of solar energy and how the energy in the environment can effect plants and animals are explored. Environmental concerns of petroleum transportation are investigated. 